\title{
TWÓRCZOŚĆ POETYCKA KOBIET NA ŁAMACH POLSKICH PISM KOBIECYCH I RODZINNYCH LAT 1865-1870
}

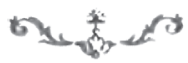

\section{PARADOKS STATYSTYCZNY}

Tiniejszy szkic ma charakter rekonesansowy. Dotyczy bowiem kwestii 1 pozostających wciąż w dość znacznym rozproszeniu zarówno, jeśli idzie o materiał źródłowy, jak i komentarz badawczy. Ponieważ jednak w ostatnim czasie przedmiotem moich analiz były kreacje „ja” podmiotowego, obecne $\mathrm{w}$ poezji kobiet $\mathrm{z}$ lat $1830-1865^{1}$, na użytek obecnego artykułu przyjrzałam się wierszom powstałym lub publikowanym chwilę później, już w okresie popowstaniowym, a jeszcze przed wyraźnym wykrystalizowaniem się nowych postaw pozytywistycznych. Interesował mnie więc czas pograniczny, między 1865 a 1870 rokiem, odniesiony do liryki kobiet, zamieszczanej na łamach najpopularniejszych czasopism kobiecych i rodzinnych, takich między innymi jak: „Opiekun Domowy” redagowany przez Adama Mieczyńskiego, „Tygodnik Mód i Nowości Dotyczących Gospodarstwa Domowego” pod redakcją Jana Kantego Gregorowicza ${ }^{2}$, „Kółko Domowe” Józefy Śmigielskiej, „Kronika Rodzinna” pod redakcją Aleksandry Borkowskiej, „Bluszcz” z okresu fak-

1 M. Berkan-Jabłońska, Zagadnienie podmiotowości w poezji kobiecej romantyzmu i okresu międzypowstaniowego. „My z nich wszystkie?”, w: Strategie „ja” (po)romantycznego w poezji polskiej XIX-XXI wieku, cz. 1: Studia i szkice, red. J. Brzozowski, K. Pietrych, Łódź 2017, s. 161-190.

2 Tygodnik przekształcił się z „Magazynu Mód i Nowości Dotyczących Gospodarstwa Domowego" w roku 1862, stopniowo zmienił nazwę najpierw na „Tygodnik Mód i Nowości z Dodatkiem Ilustrowanym Ubrań i Robót Kobiecych”, potem krócej na „Tygodnik Mód”, a wreszcie, od 25. numeru 1871 roku, na „Tygodnik Mód i Powieści”. Zob. J. Franke, Polska prasa kobieca w latach 1820-1918, Warszawa 1999, s. 80-81. 
tycznej redakcji Marii Ilnickiej ${ }^{3}$, a także kilka kolejnych tomów „Noworoczników Ilustrowanych dla Polek”. Łączy je projektowany odbiorca - w zasadniczej grupie kobiety, matki, żony, prowadzące domy, ale już niekoniecznie zadawalające się podstawowymi informacjami o świecie. Najbardziej tradycyjne wydają się w tym zestawieniu „Opiekun Domowy” i „Tygodnik Mód i Nowości” ${ }^{4}$. Pewne aspiracje naukowe wolno przypisać „Kółku Domowemu” oraz „Bluszczowi”, natomiast „Kronika Rodzinna” zajmuje na tym tle pozycję raczej umiarkowaną. Do tej listy można dodać też „Kalinę” pod redakcją Michała Bałuckiego i Alfreda Szczepańskiego ${ }^{5}$ - pismo krakowskie, kontynuujące próby Julii Goczałkowskiej z „Wieńca” 1862 roku oraz z „Niewiasty” prowadzonej przez Kazimierza Józefa Turowskiego w latach 1860-1863.

Już w roku 1861 skomentowano w „Dzienniku Literackim” zaskakujący „paradoks statystyczny” pisma Turowskiego, który był przecież udziałem także innych pism rodzinno-kobiecych i który w kolejnych latach nie uległ znacznym zmianom: „Ależ dla niewiast piszą w «Niewieście» sami prawie mężczyźni. Czy nie można by poruszyć i więcej piór światłych naszych kobiet, aby dla wzrastającego pokolenia podawały swe uwagi i rady" ${ }^{6}$.

3 Tamże, s. 101. Zob. też: J. Chwastyk-Kowalczyk, „Bluszcz” w latach 1918-1939. Tematyka społeczna oraz problemy kultury i literatury, Kielce 2003; Z. Sokół, Z badań nad polska prasa kobieca w latach 1818-1939, „Kwartalnik Historii Prasy Polskiej” 1983, R. 22, nr 3, s. 5-12; Z. Zaleska, Czasopisma kobiece w Polsce, Warszawa 1938.

4 Choć trzeba zaznaczyć, że dopuszczano w „Opiekunie Domowym” różne sposoby widzenia spraw kobiecych, np. bardzo ostrożnie i raczej zachowawczo wypowiadają się tu o emancypacji, małżeństwie i rodzinnym powołaniu kobiety Zofia z Brzozówki (Klimańska) i Oskar Stanisławski, ale obok ich głosów pojawiały się też postępowe teksty Ksawerego Drużby. Podobnie zmienne stanowiska reprezentował „Tygodnik Mód i Nowości”, pośród przeważająco zachowawczych ujęć roli kobiety drukując bez zastrzeżeń zaskakującą na owe czasy propozycję Gregorowicza, by odwrócić funkcje pełnione w społeczeństwie wedle usposobienia jednostek: mężowie mający upodobanie w strojach lub kuchni zajęliby się domem, a kobiety, jeśli są ambitne i lubią naukę, pracą (J.K. Gregorowicz, Pogadanka tygodniowa, „Tygodnik Mód i Nowości” 1866, nr 11, s. 5-6; zob. też: J. Franke, dz. cyt., s. 81-84). Jak zauważa Franke, pewne zmiany światopoglądowe nastąpiły w „Tygodniku” po publikacji rozprawy Elizy Orzeszkowej Kilka słów o kobietach („Tygodnik Mód i Nowości” 1870, nr 40-53).

5 Zarówno w przypadku „Niewiasty”, jak i „Kaliny” można mówić o formule kobiecego charakteru pisma raczej jako o pretekście dla prezentacji własnego dorobku literackiego redaktorów (zob. J. Franke, dz. cyt., s. 183-185). Z kolei na niejednoznaczny stosunek redakcji „Kaliny” do tzw. kwestii kobiecej, z inklinacjami do zachowawczych programów, wskazuje Małgorzata Stawiak-Ososińska (Rola matki w wychowaniu i kształceniu dzieci $w$ świetle artykułów z krakowskich czasopism kobiecych "Niewiasty” i „Kaliny”, „Wychowanie w Rodzinie” 2011, t. 2, s. 15-32).

6 „Dziennik Literacki” 1861, nr 103. Cyt. za: R. Jaskuła, Czasopismo „Niewiasta” (186o- 
Skądinąd liryka kobieca tego okresu nadal z pewnym trudem znajdowała sobie łamy do prezentacji. Można wszakże zauważyć, że jakkolwiek niektóre nazwiska autorek w badanym materiale prasowym powtarzają się, w większości każde z pism wyłaniało swoją dominującą „ekipę poetek-liderek”. I znów wydaje się, że najsłabszy poziom artystyczny charakteryzuje poezję kobiecą z „Opiekuna Domowego”. Najjaśniejszymi gwiazdami były tu Gabriela Puzynina i Liliana (Lilianna), czyli Zofia Wolska z Porębskich, których liryki wyróżniają się na tle mizernych prób, skądinąd bardzo płodnej, Emilii Leji, Antoniny Machczyńskiej, Józefy Żdżarskiej czy Anny S. (Skimborowiczowej). Elegijno-melancholijna poezja Puzyniny zasilała w tym czasie także szpalty „Kroniki Rodzinnej” - były to jednak już ostatnie lata jej twórczości lub wręcz, po 1869 roku, dorobek pośmiertny z rękopisów, który zapewne docierał do Borkowskiej za pośrednictwem zaprzyjaźnionej z autorką W imię Boże rodziny Sabiny Grzegorzewskiej lub Antoniego Edwarda Odyńca. Stopniowo Puzyninę zastąpiła Bronisława Pułjanowska (autorka np. wierszy $\mathrm{Ma}$ rzycielka i Dumka, chwalonych w „Bibliotece Warszawskiej” za „zarody poezji") ), Teresa Prażmowska oraz Jaskółka - prawdopodobnie Jadwiga Zeitheim ${ }^{8}$. „Tygodnik Mód i Nowości” chętnie publikował poezję Augustyny S. (Stanczykiewicz), Marii Okołów, Reginy (Regina Lewin?), Liliany, a od 1869

1863): szkic monograficzny, „Rocznik Historii Czasopiśmiennictwa Polskiego” 1973, nr 12/4, s. 480. Zob. też: A. Zyga, Krakowskie czasopisma literackie drugiej połowy XIX wieku (1860-1895), Kraków 1983. Dla potwierdzenia można zestawić kilka spisów wierszy, np. w „Opiekunie Domowym” z 1865 roku na trzydzieści pięć utworów poetyckich pojawiło się dziesięć autorstwa kobiet, w roku 1866 - na pięćdziesiąt sześć tylko trzynaście napisanych przez panie; w „Tygodniku Mód i Nowości” w 1870 na trzydzieści osiem liryków - osiem jest autorstwa kobiet. Statystyki wszędzie wyglądają na ogół podobnie. Oczywiście, nie zawsze należy te proporcje tłumaczyć złą wolą i celowym posunięciem ze strony redakcji. Wyjątkowo korzystnie wypadł 1865 rok w „Tygodniku Mód i Nowości”. Do współpracy zaproszono wówczas aż sześć autorek $\mathrm{z}$ blisko dwudziestoma wierszami.

7 Pseudonimem Bronisława posługiwały się dwie poetki - starsza Julia Janiszewska, młodsza Bronisława Pułjanowska. W tym przypadku bardziej prawdopodobne jest wskazanie na urodzoną w 1850 roku Pułjanowską, która jako nastolatka zadebiutowała w „Kronice Rodzinnej” dzięki wstawiennictwu Odyńca (zob. informacje od Redakcji, „Bluszcz” 1869, nr 10, a także: Zbiór poetów polskich XIX w., ks. 3, ułożył i oprac. P. Hertz, Warszawa 1962, s. 986).

8 Karol Estreicher w Bibliografii XIX wieku łączy z pseudonimem Jaskółka dwie autorki: Jadwigę Zeitheim i Zofię z Konarskich Bukowiecką. Słownikpseudonimów pisarzy polskich pod redakcją Jankowskiego podaje kilka rozwiązań, w których daty i tytuły prasowe pozwalają uznać obie pisarki za potencjalne autorki wierszy z „Kroniki Rodzinnej”. Jednak porównanie charakteru ich dorobku skłania mnie do przyjęcia jako bardziej prawdopodobnej wersji wiążącej pseudonim Jaskółka z Zeitheimówną. 
roku miejsce „pierwszej gwiazdy” wśród autorek zajęła Seweryna Duchińska z licznymi wierszami i tłumaczeniami lub - co częstsze - parafrazami ${ }^{9}$. Zgodnie z ideowym programem Śmigielskiej „Kółko Domowe” publikowało niewiele utworów poetyckich, kobiety reprezentowały między innymi Deotyma (Jadwiga Łuszczewska), Puzynina, Julia Janiszewska.

Z kolei „Bluszcz” proponował czytelnikom i czytelniczkom wiersze na przykład Marii Jadwigi (Florentyna Włoszkowa z Domaszewskich: Ranek i wieczór, Dzień Zaduszny), kilka tekstów pióra Puzyniny i Deotymy, ale przede wszystkim poezję Marii Ilnickiej. Jej utwory z wielką regularnością wypełniały w pierwszych latach działalności pisma dział literacki, dopiero od 1871 roku zostały zastąpione w przeważającej większości wierszami mężczyzn, takich jak: El...y (Adam Asnyk), Klemens Podwysocki, Tomasz Zawadyński czy Stanisław Grudziński.

\section{MOTYWY I NASTROJE}

Gros wierszy publikowanych na łamach wymienionych periodyków ${ }^{10}$ kontynuuje typowy dla wcześniejszych dekad wzorzec poezji moralizującej, w którym kobiecy podmiot na podstawie jakiejś scenki z rzeczywistości formułuje zasady właściwego postępowania lub wzywa do zmiany postaw w zgodzie z religią i tradycyjnymi wyobrażeniami na temat roli kobiety (np. Jaskółka, Matka i dziecię, KR 1868, nr 10; Antonina Machczyńska, Dziadek wiejski, OD 1865, nr 23; Amelia Pruszkowa, Wesele jedynaczki, OD 1870, nr 8 ${ }^{11}$; Maria Ilnicka, Po balu maskowym, B 1868, nr 7; Gabriela Puzynina, Procesja Bożego Ciała, B 1867, nr 26; taż, Żal i żal. Do pani $i^{* * *}, \mathrm{KR}$ 1868, nr 4). Z pochwałą pobożności i cnoty wiążą się motywy heroicznego zmagania z losem oraz udręczenia cierpieniem i troskami, niedostrzeganymi przez świat zewnętrzny, które wciąż przez wiele poetek bywały uznawane za nieodłączny atrybut kobiecego losu. Niestety, w warstwie językowej i stylistycznej problematyka ta przynosi mierne efekty, pozbawione w większości oryginalnego ujęcia (m.in.

9 W „Tygodniku Mód” ukazywały się również przez całe dziesięciolecia jej korespondencje z Paryża oraz liczne tłumaczenia popularnych powieści.

10 Przy wymienianiu konkretnych tytułów wierszy w tekście głównym stosuję dalej następujące skróty nazw czasopism: OD - „Opiekun Domowy”, KR - „Kronika Rodzinna”, KD - „Kółko Domowe”, B - „Bluszcz”, TMiN - „Tygodnik Mód i Nowości”, TM - „Tygodnik Mód”, K - „Kalina”, NRI - „Noworocznik Ilustrowany...”, N -, Niewiasta”.

11 Amelia P. (Amelia Klara Pruszakowa) publikowała swoje utwory w „Opiekunie Domowym” i w „Kalinie”. Była także autorką tomiku Poezje (Warszawa 1869). Autorstwo rozwiązuje Rozalia Wojkiewicz, współautorka Bibliograficznej bazy adnotowanej „Poezja na marginesie cywilizacji” https://pnamc.ehum.psnc.pl/pnamc/d/31726. html [dostęp 2017-10-20]. 
Janiszewska, Ora et labora, KD 1865, nr 17; Stanczykiewicz, Spłacony dtug, TMiN 1865, nr 27; [b.a.], Równianka, „Kalina” 1867, nr 27; Ewelina S., Ślub, TMiN 1865, nr 36; Ilnicka, W próbie, B 1867, nr 10; Prażmowska, Rada dziewczynce, KR 1868, nr 13; taż, Uśmiechy życia, KR 1868, nr 2). Wiele możemy też wskazać liryków, które z rozpoznania zbieżności losu kobiety i zjawisk natury wyprowadzają proste prawdy życiowe, najczęściej o charakterze pocieszenia dla potencjalnych czytelniczek (np. Stanczykiewicz, Obrazek sielskiej wiosny, TMiN 1868, nr 24; Puzynina, Dziś, KR 1867, nr 3; taż, Niezapominki, B 1868, nr 21; Bronisława, Wiosna, KR 1870, nr 17; taż, Żeglarz, KR 1870, nr 19; Regina, Ptaki, TMiN 1866, nr 49; Liliana, Po burzy, TMiN 1865, nr 15). Refleksja ustępuje na ogół przed impresyjnością i ulotnością doznań jednostki, tak jak na przykład w wierszu Marii Jadwigi Wieczór i ranek (B 1867, nr 5), gdzie poczucie bliskości z naturą, momentami nawet oryginalnie zobrazowane, ostatecznie zamknięte zostaje truizmem „świat jest piękny”. Dominującym rysem tej poezji wydaje się nadal nastrój melancholijno-elegijny, choć przyjdzie się do tego jeszcze odnieść szerzej ${ }^{12}$. Motywy arkadyjskie zazwyczaj płynnie przechodzą w obrazy rozpoznawanego stanu utraty, poczucia rozczarowania, przeświadczenia o niemożności powrotu do dawnej harmonii z powodów od kobiety niezależnych, wobec których azylem okazuje się trwałość ludzkiej pamięci lub współczucie Boga (np. Augustyna Stanczykiewicz, Gdzie szczęście?, TMiN 1868, nr 35; taż, Chwilka nad wieczorem, TMiN 1867, nr 26; Prażmowska, Rozum a mądrość, KR 1870, nr 10). Do tego, choć zdecydowanie rzadziej niż w dobie przedpowstaniowej, znaleźć można w analizowanych czasopismach wiersze pełne poromantycznej egzaltacji i utrzymane w poetyce anachronicznego już typu bajronicznego. Wątek jednostki niezrozumianej przez zbiorowość, pogrążonej w bólu i rozpaczy, tudzież marzącej o śmierci, pojawia się między innymi w liryku Cicho Stanczykiewicz (TM 1869, nr 4), tejże, Powrót nad rodzinną rzeczkę (TMiN 1865, nr 36), Liliany, Czegóż ja pragne (TMiN 1867, nr 18), w Sierocej doli Bronisławy (KR 1870, nr 13) lub Smutnej Jaskółki (KR 1871, nr 14).

Szczególną grupę stanowią wiersze, które - za Adamem Grzymałą-Siedleckim - nazwać można "grottgeryzmami” ${ }^{13}$. Największą ich reprezentację

12 Interesujące, że właśnie ów melancholijny rys Urszula Chowaniec-Pozo (Melancholia i depresja w literaturze pisanej przez kobiety po 1989 roku, „Annales Universitatis Paedagogicae Cracoviensis. Studia Historicolitteraria” 2009, nr 9, s. 129-143) uznaje za ważny trop kobiecego pisania w literaturze współczesnej. Zob. też: J. Bator, Miłość i melancholia. Saturniczny wymiar istnienia męskości i kobiecości (esej antropologiczny), w: Gender w humanistyce, red. M. Radkiewicz, Kraków 2001.

Cyt. za: A. Zyga, dz. cyt., s. 84-85. 
znajdujemy na łamach „Kaliny”. To tak zwana poezja „grobowa”, „cmentarna", którą pismo publikowało, a zarazem - w odniesieniu do wielu autorów krytykowało. W jej kobiecych wariantach treści patriotyczne wyznaczają obrazy Polki-ofiary drugiego planu: zmuszonej żegnać zmarłych bliskich, czekać na wygnanych i znosić trudy samotnego życia (np. [b.a.], Szczęście, „Kalina” 1867, nr 8; Amelia Pruszakowa, Oczekiwanie oraz Wygnanie, K 1867, nr 18; A. Stanczykiewicz, Wianki sieroce, TMiN 1869, nr 10; Deotyma, Kółko domowe, KD 1861, nr 1). Część jednak liryków kobiecych, które choćby aluzyjnie odsyłają nas do doświadczeń powstania styczniowego, łączy silna potrzeba zastąpienia poetyki „łez” wariantem „konstruktywnym”, który mógł oznaczać zarówno wyeksploatowany literacko motyw heroicznego poświęcenia, jak i zwrot ku praktyce życia kobiecego oraz wzmacniania podnoszącej na duchu wspólnoty (np. Alma K., Nie zwij sierotą, K 1867, nr 8) ${ }^{14}$. Na tle tych w większości nadal epigońskich propozycji poetyckich ${ }^{15}$, zwłaszcza gdy brać pod uwagę środki ekspresji literackiej, wyróżnia się pozytywnie dumka Kalina Malwiny Świstelnickiej. Stylizacja ludowa, nasuwająca skojarzenia ze szkołą ukraińską Józefa Bohdana Zaleskiego, oraz prosta treść oparta na tak lubianej przez kobiety relacji między doświadczeniem natury a doświadczeniem ludzi przyniosły efekt w postaci bezpretensjonalnego obrazka. Zaletą liryku czytanego po latach okazuje się też prosty język, pozbawiony manierycznych zdrobnień i patosu, choć niewolny od rozmaitych clichées.

Na kalinie siadło ptaszę,

Szaropióre - ale nasze,

Wzniosło w górę głos:

Skrzydełkami strzepotało,

Zaśpiewało - zapłakało

Na swój biedny los!

Cyt, ptaszyno - cyt, ma ptaszko,

Wszystkim życie nie igraszką,

Rzekł kaliny krzew:

W moim krzakuś się zrodziła,

Tu cię matka hołubiła,

Tuś poczęła śpiew! ${ }^{16}$

14 Czasem wręcz ścierają się te literackie głosy. Wiersz Almy K. Nie zwij sierotą stanowi odpowiedź na wcześniejszy liryk Sieroty podpisany K...a (prawdopodobnie Aleksandra Konarska; „Kalina” 1867, nr 2).

15 Wiersze kobiet rzadziej jednak apoteozowały Polkę w smutku i żałobie niż wiersze mężczyzn, których wizja kobiety-patriotki była pozbawiona wszelkiej ambiwalencji, np. Aleksander [N. Rembowski], Nowa Magdalena, „Kalina” 1868, nr 22; Br. Ło. [B. Łoziński], Spartanka-Polka, „Kalina” 1868, nr 13.

M. Świstelnicka, Kalina, „Kalina” 1867, nr 1, s. 4-5. 
W kolejnej strofie na ten obraz nakłada się płynnie portret młodej dziewczyny w opustoszałym gnieździe rodzinnym, której los budzi autentyczne współczucie podmiotu: „Z serca mi cię żal!”. Pozbawiona nadziei historia wygnańców „wśród śniegów z łaski carskiej” wywołuje chwilowy bunt wyrażony pytaniem: „czyż nie będzie dnia odpłaty”, ale wygrywa z nim pociecha płynąca z przekonania o jednakich doświadczeniach istot żywych, sile współczucia i sile pamięci:

A tymczasem - Pan Bóg z nami!
Weź mą gałąź z jagodami
Wiej się w chmury, wiej!
I leć światem het szeroko,
Gdzie zaniesie Bóg i oko
I po świecie siej! ${ }^{17}$

Również w Komecie Almy K. (podtytuł: Tekst do pierwszego obrazu $z$ „Wojny” A. Grottgera) udało się odejść od wzniosłych eksklamacji na rzecz budowania udramatyzowanej scenki z życia polskiego dworku i oddać atmosferę niepokoju, lęku przed nadchodzącymi zmianami: „I każdy z trwogą pogląda przed siebie / I z drżeniem pyta: «Boże, co to będzie?»" ${ }^{18}$. Opowieść o jednej rodzinie staje się tutaj alegorią narodowego doświadczenia, w zgodzie z przesłaniem malarskiego pierwowzoru.

Przy tej okazji dodajmy też, że częściej niż w latach minionych kobiety autorki podejmują tematykę korespondencji sztuk (np. Puzynina, Niewiasty święte u grobu Chrystusa [Do obrazu Simlera], B 1866, nr 55; Ilnicka, Wit Stwosz. Pod obrazem Matejki, B 1868, nr 26; taż, U grobu pańskiego [Pod obrazem Simmlera Trzy Marie], B 1868, nr 14; taż, U stóp Najświętszej Panny z lampa. Dłuta Władysława Oleszczyńskiego, B 1866, nr 38), i nawet jeśli są to tylko swobodne wariacje inspirowane malarskim wyobrażeniem, trzeba dostrzec w nich ważne poszerzenie źródeł inspirujących tę poezję.

Wśród wierszy autorstwa kobiet tego okresu odnajdujemy również więcej stylizacji ludowych, na przykład Stanczykiewicz, Pieśń Franka (TMiN 1867, nr 46), Dzień Zaduszny Marii Reginy (B 1867, nr 45), Duchińskiej, Kochanie. $Z$ Petöfiego (TM 1870, $\mathrm{nr}$ 23), a przede wszystkim liryki i wierszowane obrazki pióra Liliany, np.: Góral [Myśl z obrazka Gersona] (OD 1865, nr 18), Juhas wegierski (OD 1865, nr 42), Wiejska pastuszka (OD 1867, nr 34), Troskliwość kochanki. Serbska piosenka (TMiN 1865, nr 14), Powrót górala (OD 1869,

17 Tamże.

18 Alma K., Kometa (Tekst do pierwszego obrazu z „Wojny” A. Grottgera), „Kalina” 1868, nr 19, s. 4. 
nr 39). Stosowany tu najczęściej model liryki roli można tłumaczyć częściowo jako wybieg pozwalający uniknąć kontrowersyjnego lub też stygmatyzującego piętna kobiecości ${ }^{19}$, ale też jako wyraz nowych fascynacji górskim pejzażem i kulturą, które w warstwie stylistycznej skutkowały techniką synestezyjnego opisu i poetyką epifanii. Nie dostrzegam w nich natomiast zabarwienia społecznego, w większości stanowią pokłosie romantycznej emocjonalności, która idzie w parze z estetyzacją rzeczywistości i idealizacją czy wręcz heroizacją ludowych bohaterów.

\section{LIRYKA MENOPAUZALNA}

Odrębnej analizy, jak sądzę, wymagałaby natomiast poezja, którą roboczo określiłam mianem „menopauzalnej”, np. Liliany Liście jesieni (TMiN 1867, nr 26); anonimowy Żal (TMiN 1868, nr 15), Wspomnienie (TMiN 1868, nr 16). W pobieżnym czytaniu wiersze te wydają się dość typową realizacją „łzawego” nurtu liryki kobiecej okresu poromantycznego, szufladkowaną jako nostalgiczno-elegijna. Tymczasem powiązanie nastroju głębokiego smutku z poczuciem fizycznego „obumierania” i trudnościami w akceptacji procesu przemijania (ewentualnie z gorzką zgodą na inną siebie - pozbawioną sił młodości i cielesnego uroku) skłania do lektury bardziej przychylnej autorkom tych wierszy - uwarunkowanych biologicznie, swoiście kompensacyjnych, jakkolwiek nadal - zwłaszcza w zakresie leksyki - szalenie stabuizowanych. „Życie przy schyłku mało ma uroku” - pisze w Wyjątku z rocznicy urodzin Liliana (TMiN 1865, nr 2). Tak chyba można by czytać również przedpowstaniowy wiersz Ilnickiej Strącona, w którym refleksja wywołana obserwacją spadającej gwiazdy odnosi się bezpośrednio do losu kobiety:

$$
\begin{gathered}
\text { Czyś ty zgasła jak weselna } \\
\text { Lampa z rana? } \\
\text { I kiedy cię noc tajemna } \\
\text { W otchłań parła, } \\
\text { Czyś ty była bryła ciemna } \\
\text { I zamarła? } \\
\text { Czyś ty drżała tą straszliwą } \\
\text { Trwogą w sobie, } \\
\text { Jak ten, kogo z piersią żywą } \\
\text { Kładą w grobie? }{ }^{20}
\end{gathered}
$$

19 O takich zabiegach zacierania atrybutów kobiecości pisała przy okazji młodopolskich poetek np. Anna Legeżyńska, której rozpoznania są dla mnie ważnym punktem odniesienia w wielu miejscach tego szkicu. Zob. A. Legeżyńska, Od kochanki do psalmistki... Sylwetki, tematy i konwencje liryki kobiecej, Poznań 2009 (zwł. cz. 1). M. Ilnicka, Strącona, „Tygodnik Ilustrowany” 186o, nr 20, s. 163. 
Inaczej niż zwykło się to czynić, należałoby interpretować również niektóre, pozornie sentymentalne obrazki z natury, szczególnie jeżeli dotyczą miłosnych relacji. Piosneczka Reginy (TMiN 1865, nr 41), opis białej brzozy nękanej przez dąb a chronionej przez wiatr, to zastępczy pejzaż erotyczny, zrodzony z przeniesienia emocji, napięć, niepokojów. Na ile było to czytelne dla ówczesnych kobiet, trudno jednoznacznie ocenić. Jakkolwiek wiersz reprezentuje ten typ wrażeniowości i intymistyki, który daleko odbiega od współczesnej estetyki, to jednak niewątpliwie koreluje z młodopolską sublimacją uczuć ${ }^{21}$, i choćby dlatego otwiera pewne tropy badawcze. A nie jest to przecież odosobniony przykład.

\section{FRAGMENTY DYSKURSU EMANCYPACYJNEGO}

Z kolei refleksem zmian ideowych, jakie zapowiadają przełom pozytywistyczny, jest stopniowe wygaszanie motywów fantastyczno-bajronicznych w wersji kobiecej, zastępowanych pochwałą nauki, wiedzy i ciekawości poznawczej. Anna Skimborowiczowa deklaruje w wierszu Kobieta: „Nauko! życia pociecho, osłodo! / [...] Tyś przyjaciółka, towarzyszka droga / Złamanych ciałem, a silnych na duszy" ${ }^{22}$. Kwestie edukacji, tak często poruszane na łamach prasy, przekładają się na nieśmiało jeszcze artykułowane przez podmiot liryków kobiecych pragnienia przekroczenia czterech ścian własnego domu i doświadczania nowych wrażeń ([b.a.], Co ja lubię, TMiN 1868, nr 26).

Wątki prepozytywistycznego utylitaryzmu i pragmatyzmu przybierają kształt lirycznego wezwania do życia aktywnego i walki z izolującymi kobietę od codzienności marzeniami. Takie postulaty pojawiają się między innymi u Ilnickiej (Do znudzonej, KD 1865, z. 22; tejże, Słuchaj dzieweczko, B 1866, nr 52), Eweliny (Badowskiej) (Do niepewnej, B 1868, nr 44) lub Puzyniny (Do młodej panienki, OD 1869, nr $6^{23}$. Celuje w tej tematyce zwłaszcza Duchińska, sama niezwykle pracowita i czynna na wielu płaszczyznach życia. W wierszach Do Natalii [ofiarowujac jej kwiat jabłoni] (TMiN 1869, $\mathrm{nr}$ 2), Do siebie (TM 1870, nr 32) i Do jedwabnika. Wiersz skreślony nad jeziorem Como w kraju jedwabników (TM 1869, nr 33) podkreśla praktyczny wymiar życia, nawołuje, by „siać ziarno”, wskazuje na wartość pracy niezbędnej dla rozwoju własnego i społecznego. Jednak i w jej dorobku poetyckim tego okresu znajdujemy tek-

21 Zob. bardzo zbliżone ustalenia dotyczące poezji młodopolskiej - A. Legeżyńska, dz. cyt., s. 24-37.

22 Anna S. [A. Skimborowiczowa], Kobieta, „Opiekun Domowy” 1868, nr 2, s. 11-12.

23 Wiersz Puzyniny był kilkakrotnie przedrukowywany: najpierw w „Tygodniku Ilustrowanym” (1868, nr 14, s. 163), potem w „Kalinie” (1869, nr 27, s. 1) i „Wieczorach Rodzinnych" (1880, nr 51, s. 767). 
sty, w których literatka nagle dystansuje się od ambicji emancypacyjnych kobiet, restytuując obraz kobiety-anioła jako celu dążeń wbrew zamiarom „nowych Ew” (Co lubi kobieta, TM 1869, nr 25). Niezależnie od różnej wartości artystycznej omawianych tu liryków, trzeba dostrzec w nich próbę przełamania silnie zakorzenionej w dysputach epoki „binarności” myślenia na temat umysłów kobiet i mężczyzn.

\section{KOBIECE METATEKSTY}

Wiersze Duchińskiej inicjują też wątek bardzo ważny z perspektywy rozwoju poezji kobiet, choć - niestety - w tym czasie rzadziej obecny niż w dobie przedpowstaniowej: metatekstowość. Liryk $W$ noc miesięczna ma postać dialogu z księżycem, od dzieciństwa inspirującym poetkę do tworzenia, będącym duchem opiekuńczym w świecie poezji i nazywanym jedynym przyjacielem. Słowa pozornie deprecjonujące wartość własnego pisania:

Nowi tobą gardzą wieszcze,

[...]

Mnie śpiewaczce, w wieszczów gronie

Więc spoglądam ku tej stronie,

Skąd miesiącu świecisz blady ${ }^{24}$

- z jednej strony potwierdzają rozeznanie autorki w bieżących dla niej tendencjach literackich, a z drugiej, świadczą o celowej grze z czytelnikami, w której ramach brak ewentualnych kwalifikacji twórczych staje się atutem: daje bowiem podmiotowemu ,ja” prawo użytkowania języka i wątków poetyckich wedle uznania, autonomizując go. Degradacja paradoksalnie wyzwala ${ }^{25}$.

Ja wspominam cię w mej pieśni,

Ja cię w moim pieszczę duchu,

Niech wyszydzą mnie współcześni,

Lecz ty nie szydź stary druhu!

[...]

Ja po srebrnym tym promieniu,

W nieskończone mknę obszary,

W sennej ciszy - w nowym cieniu. ${ }^{26}$

24 S. Duchińska, W noc miesięczną, „Tygodnik Mód” 1870, nr 18, s. 1.

25 Magdalena Siwiec zwracała uwagę, że „zdefiniowanie własnej twórczości w sposób negatywny - przez brak - dowodzi zdolności głębokiej analizy” (M. Siwiec, „Kobiety, wiem to, pisać nie powinny; / A jednak pisze...”. Romantyczna poetka i jej Muza, „Teksty Drugie” 2009, nr 3, s. 19).

26 S. Duchińska, W noc miesięczną, s. 1. Zob. też np. Duchińska, Do pieśni (KR 1870, nr 18); Ilnicka, Do młodego poety (B 1866, nr 1); Bronisława, Dumka (KR 1869, nr 11). 
Przykład Duchińskiej dobrze również ilustruje trudność, jaką przysparza ocena poezji kobiet tego okresu. Rzadko możemy mówić o jednorodnym charakterze ich twórczości, próbują swych sił, podejmując rozmaite tematy i formy gatunkowe, zaś artystyczne rezultaty bywają skrajnie różne ${ }^{27}$. Obok udanych liryków, czasem nawet zaskakująco dobrych, znajdujemy w dorobku takich literatek, jak choćby Duchińska, Puzynina, Ilnicka, wiele realizacji po prostu grafomańskich. Zatrzymam się przez moment przy poezji Ilnic$\mathrm{kiej}^{28} \mathrm{z}$ racji jej reprezentatywności dla kobiecego pisarstwa. Ilnicka stoi na straży bardzo tradycyjnych wartości rodzinnych, jest też przekonana o perswazyjno-dydaktycznej roli słowa. W wielu wierszach, „gładkich, zręcznie rymowanych, pełnych szlachetnej, idealistycznej tendencji” ${ }^{29}$ zachęca do godnego znoszenia trudów życia kobiety i dość konserwatywnie pojmowanego zaangażowania w rzeczywiste problemy codzienności. Jej styl jest poprawny i umiarkowanie sentymentalny, ale wykazuje skłonność do patosu i inwokacyjności. Zarazem jednak obok wielu konwencjonalnych, niemal okolicznościowych utworów, jak choćby Życzenie (B 1865/1866, nr 14), Stuchaj dzieweczko (B 1866, nr 52), Do młodej oblubienicy (B 1867, nr 9) czy Do złotowłosej ( $\mathrm{K}$ 1869, nr 1), są w jej dorobku poetyckim inne teksty, wskazujące zarówno na nieoczywistą interpretację miejsca kobiety w świecie, jak i na pewną innowacyjność warsztatu. Ta ostatnia polega między innymi na zastępowaniu prostej konfesyjności rozmaitymi formami ekwiwalentyzowania stanów psychicznych ,ja” poetyckiego. Już w okresie przedpowstaniowym Ilnicka próbowała oddać emocje i rozterki kobiece, sięgając po tradycyjnie przypisywane kobietom autorkom wątki i leksykę (np. implikowaną obrazami natury), by nadać im znaczenia nowe, dokonać swoistego demontażu „matryc”. Mam wrażenie, że tak właśnie wolno czytać na przykład wiersze Bluszcz (B 1865, nr 1) lub Naucz mnie twojej piosenki (B 1867, nr 33). Korzystnie wypadają zwłaszcza te utwory, w których Ilnicka unika zbyt jednoznacznej puenty, nacechowanej dydaktycznie. Bywa, że w jej miejsce wprowadza niesłychanie rzadką w poezji ówczesnych kobiet ironię, jak choćby w króciutkim liryku-westchnieniu Do ślicznej...:

27 Uwaga ta odnosi się tak do badanych tekstów jako całego zespołu, jak i twórczości poszczególnych autorek, i musi wywoływać pytania o powody takiej ambiwalencji celów, poetyk, figur „ja” podmiotowego, źródeł wpływów literackich bądź ogólniejszych - społecznych, środowiskowych, a nawet ekonomicznych.

28 M. Hulewiczowa, Ilnicka z Majkowskich Maria, w: Polski Słownik Biograficzny, t. 10, Wrocław 1962-1964, s. 155-156.

29 Tamże, s. 155. 
$\mathrm{O}$, śliczna pani w kwiaty strojna Jak ty szczęśliwa jesteś pewnie? O wszystko drogie ci spokojna, I nie płacząca nigdy rzewnie, Tak rzewnie - ciężko - tak boleśnie, Że serce potem łka, choć we śnie.

Tak! Ty, wesołe życia dziecię,

Nie musisz smucić się po niczym:

Bo któż inaczej wieńce plecie,

Gdy wieniec zgodą jest z obliczem,

Oblicze z sercem?... Więc szczęść Boże,

Motyla wróżko - w muszek dworze!... ${ }^{30}$

Dzięki ironicznej metaforze z ostatniego wersu czytelnik zostaje wytrącony z przyzwyczajenia "moralizującego”, a podmiot kobiecy zyskuje zdolność dystansu i nową podmiotowość wyrosłą ze świadomie zerwanych więzi siostrzanych (strategia ta nieobca bywała też poezji Narcyzy Żmichowskiej).

\section{WATTKI PREMODERNISTYCZNE}

Na szczególną uwagę zasługuje wiersz Krajobraz zimowy. Rezygnuje w nim Ilnicka zarówno z bezpośredniej wypowiedzi ,ja” lirycznego, jak i z inwokacji do adresata/adresatki, a więc dwóch znamiennych atrybutów kobiecego pisania; unika dydaktycznej lub moralizującej puenty. Idzie o krok dalej, proponując pozbawiony komentarza opis świata pogrążonego w śnieżnej otulinie, jakby zamkniętego na zewnętrzne impulsy. Odpowiadają tej wizji wersy nieregularne, rymy zbliżone, nie zawsze dokładne, przerzutnie...

Nic się ostro nie jeży,

Całun śnieżnej odzieży

Zaokrąglił kant wszelki łagodnie:

Wszystko jedno ma znamię,

Wzrok się z niczym nie łamie,

W dal bezkształtną się ślizga wygodnie ${ }^{31}$

Myślę, że wolno widzieć tu zapowiedź niektórych właściwości kobiecej poezji modernistycznej. W przeciwieństwie jednak do światów duszy młodopolskich poetek opis Ilnickiej zachowuje ścisły związek z doświadczeniem realnym, choć perspektywa ludzka wprowadzona zostaje dopiero w zakończeniu:

Nic się nie rwie do słońca,

W jasny przestwór bez końca,

30 M. Ilnicka, Do ślicznej..., „Bluszcz” 1866, nr 24, s. 101.

31 M. Ilnicka, Krajobraz zimowy, „Bluszcz” 1871, nr 3, s. 17. 
Tylko widać kolumnę gdzieś dymną.

Ludzie cicho, jak duchy,

Przez śniegowe brną puchy,

A spotkawszy się mówią - że zimno... ${ }^{32}$

Lakoniczne zawieszenie $\mathrm{z}$ finału nadaje temu tekstowi niejednoznaczną wymowę i nowoczesne brzmienie.

W tym kierunku rozwijała się również poezja Augustyny Stanczykiewicz. W liryku Krzak róży i śnieg (TMiN 1868, nr 12) obserwujemy podobne odejście od wypowiedzi pierwszoosobowej, rezygnację ze stroficznej budowy wiersza o rytmiczności piosenki na rzecz jeszcze dość oczywistego, ale usymbolicznionego obrazu relacji tytułowych postaci (krzak róży - śnieg). Opis ich wzajemnych zachowań motywowanych afektami, iluzjami, ambicjami prowokuje pośrednio pytanie o źródła analogicznych nieporozumień w świecie ludzkim, a w przestrzeni literackiej wywołuje skojarzenie z młodopolskimi lirykami tatrzańskiego cyklu Jana Kasprowicza.

Z kilku powodów wyróżnijmy Ewelinę Badowską, której utwory drukowały i pisma kobiece, i prasa przeznaczona dla szerszego odbiorcy, np. „Tygodnik Ilustrowany”. Wiersz Do niepewnej, gdy rozpatrywać jego treściową zawartość - pozostaje zgodny z biedermeierowską (lub w pewnej mierze prepozytywistyczną) koncepcją człowieka silnego, podnoszącego się z głębokiego rozczarowania, gotowego uwierzyć w sens pracy i czynu, z zastosowaniem wszystkich tych idei do życia kobiety. Nie byłby więc może szczególnie oryginalny, gdyby nie próba innej dykcji niż tradycyjnie przypisywana kobietom śpiewna fraza i tkliwość. Badowska odchodzi od układu stroficznego, stosuje liczne przerzutnie, wydłuża wers do trzynastu, czasem czternastu zgłosek, uzyskując tym samym efekt spokojnej wypowiedzi o charakterze dyskursywnym ${ }^{33}$. Wspiera go otwierające wiersz zdanie: „Pytasz, młoda kobieto, czy życie stargane / Można uczynić jeszcze życiem czynu, pracy" ${ }^{34}$, co sprawia, że czytelnik ma wrażenie wejścia w rozmowę in medias res. A zasadniczą zaletą utworu, decydującą w moim przekonaniu o ciekawym kierunku rozwoju tej poezji, jest oddanie doświadczenia kobiecych wątpliwości, wahań, zwątpień nie językiem wyłącznie afektów, lecz także ich dojrzałej racjonalizacji. Również w innym utworze tej autorki, Pamiętam, elegijno-nostalgiczny nastrój wierszowanego wspomnienia rodzinnego domu, łączy się z ujętą w epickie ramy historią utraty dziecinno-młodzieńczych wiar i ich późniejszego

Tamże.

33 Anna Legeżyńska (dz. cyt., s. 20) stosuje w tym kontekście termin „narratologia”.

34 Ewelina [E. Badowska], Do niepewnej, „Bluszcz” 1868, nr 44, s. 277. 
przywrócenia. Poetka udanie oddaje rytm mowy potocznej dzięki licznym powtórzeniom, pytaniom retorycznym, elipsom, przerzutniom.

I uwierzyłam słowom matki ukochanej,

I znowu bóstwom w duchu stawiałam ołtarze.

Ale czemuż ich szaty tej niepokalanej

Nie mają już białości, i czemu ich twarze

Odmienne? - a ja tamte, jak gdybym je wczora

Widziała, tak pamiętam co dnia, co wieczora... ${ }^{35}$

\section{KRYTYKA WOBEC POEZJI KOBIECEJ}

Na marginesie poczynionych dotąd spostrzeżeń warto odnieść się do kwestii stosunku ówczesnej krytyki względem obecności kobiet w literaturze czy to w roli bohaterek, czy to autorek. Jakkolwiek na łamach wybranej przeze mnie prasy w latach 1865-1870 ze znaczną intensywnością były omawiane edukacyjne czy też społeczne aspekty tak zwanej kwestii kobiecej ${ }^{36}$, do bieżącego piśmiennictwa kobiet, a zwłaszcza ich dokonań poetyckich, odnoszono się sporadycznie ${ }^{37}$. W 1867 roku „Bluszcz” opublikował natomiast artykuł Kobieta wobec poezji autorstwa Floriana (Stanisława Marka Rzętkowskiego) ${ }^{38}$. Jeszcze przed zasadniczymi opracowaniami Michała Bałuckiego i Piotra Chmielowskiego o bohaterkach literackich ${ }^{39}$, publicysta „Bluszczu” przypominał, że dotychczasowe przedstawienia kobiet w literaturze tworzone przez mężczyzn są niewystarczające, zawieszone między „ubóstwieniem” a „pohydą” kobiety. Pisał: „Jeżeli zawoła: Jestem kobietą! -

Ewelina [E. Badowska], Pamiętam, „Tygodnik Ilustrowany” 1868, nr 26, s. 305.

36 Oczywiście w różnych ujęciach - tak zachowawczych, jak umiarkowanych bądź postępowych. Dla przykładu wymieńmy tylko kilka tytułów: J.K. Gregorowicz, Pogadanki tygodniowe, TM 1866-1867; Z. Dobieszewski, Słówko o kongresie kobiet w Lipsku, KD 1865, nr 24; H. Struve, O emancypacji kobiet, KR 1867, nr 4; M. Ilnicka, Kształcenie kobiety przez kobiete, B 1868, nr 28, 32; M. Ilnicka, O nowych zawodach kobiety, B 1871, $\mathrm{nr}$ 30; J. Belejowska, Wychowanie publiczne, TM 1869, nr 10; [b.a.], O uczoności kobiet, KR 1868, nr 8-9; A. Goltz, Reforma w wychowaniu kobiet i w użyciu ich czasu i pracy, KR 1869, nr 7-10; J. Otton Bochwic, Mężczyzna i kobieta, OD 1870, nr 20; Zofia z Brzozówki [Z. Klimańska], Słówko o nauczycielkach, OD 1869, nr 29; Artykuł pana Nowosielskiego „O kwestii kobiecej”, TM 1870, nr 26 itp.

37 Chętnie pisano o literatkach dawnych, np. Elżbiecie Drużbackiej, Klementynie Hoffmanowej lub Marii Wirtemberskiej.

38 Florian [S.M. Rzętkowski], Kobieta wobec poezji, „Bluszcz” 1867, nr 35 (s. 141-142), nr 37 (s. 149-150). Przy cytatach z tej pracy w nawiasie umieszczam numery stron.

39 M. Bałucki, Kobiety dramatów Słowackiego, „Kalina” 1867, nr 5-11, 14-15, 26-28 (wyd. książkowe: Kraków 1868); P. Chmielowski, Kobiety Mickiewicza, Słowackiego i Krasińskiego, Warszawa 1873. 
nie usłyszą jej” (s. 141), słusznie wypominając współczesnym poetom, że idealizacja, tak częsta względem „płci pięknej”, opiera się przede wszystkim na przymiotach zewnętrznych kobiety. „Dlaczego w poezji naszej nie przedstawiono dotąd kobiety w pełni jej woli i czynu?" (s. 142) - zastanawiał się, analizując dalej powiązania literatury z rzeczywistymi potrzebami życia wewnętrznego kobiet. Oryginalnym elementem jego wykładu było zwrócenie uwagi na kwestie swobody kobiety, którą rozumiał w istocie jako odrębność, samoistność jej człowieczeństwa. Poezja polska - jak twierdził:

[...] przedstawiła kobietę jako obiekt, jako przedmiot, ze wszystkimi cechami przedmiotowości. Stawiała ją zawsze zależną od mężczyzny, i tylko w stosunku do niego. [...] Dopiero życie praktyczne, albo raczej potrzeby, wywołujące energiczne i samodzielne wystąpienie kobiety, mogą stać się przyczynami takiego odosobnienia. [...] Nie orzekłszy nic w tym przedmiocie, wykazała mimo woli kobiecie potężną prawdę. (s. 142)

Jednocześnie rozpoznawszy ten brak wobec stanu rzeczywistego i uświadomiwszy sobie, że zmiana mentalności już się dokonała, autor nie potrafił wyjść poza standardowe formułki o naturalnym instynkcie kobiet, który dzięki równowadze woli, rozumu i uczucia mógłby ochronić ją przed „wynaturzoną emancypacją". Ponieważ Florian definiował poezję poromantycznie - jako przestrzeń emanacji uczuć i poszukiwania duchowości - nie uważał za stosowne oddać głosu samym kobietom i nie próbował też ocenić propozycji współczesnych mu poetek. Rozpoczynając więc od bardzo trafnych spostrzeżeń historycznoliterackich, Rzętkowski nie doszedł do żadnych innowacyjnych wniosków. Podobnie bywało z pojedynczymi recenzjami kobiecej liryki. Jeśli już pojawiały się $e^{40}$, były pobieżne i operowały liczmanami na temat pięknego obrazowania i siły uczuć. W większości mamy w nich do czynienia z quasi-pochwałami, które negowały świadomość artystyczną autorek, ich podmiotowość i autonomię poetycką. Podnoszona była w zamian wartość szczerości i naturalności, które sytuowały tę poezję w przestrzeni domowej, peryferyjnej. Dobrze oddaje ten mechanizm fragment recenzji tomików Anny Libery (Krakowianki) w „Kalinie”. Autor Przeglądu podkreśla $\mathrm{z}$ aprobatą:

Zob. np. E. Stawiski, Improwizacje i improwizatorowie, KR 1867, nr 11, s. 180; Stanisława P., Anna z Krakowa, „Kółko Domowe” 1865, nr 11, s. 161-162. Przedruk tej ostatniej publikacji w „Opiekunie Domowym” (1869, nr 45, s. 354-355) poprzedzony został następującym uzasadnieniem ze strony redakcji: „Będzie to najlepszym dowodem, że kobietom nie odmawiamy uznania, gdy pracują zacnie i na polu literackim, choćby z mniejszą zdolnością...”. 
Nie były to więc utwory pisane dla księgarzy, dla sławy - ale spowiedź duszy cichej kobiety, jej sny i marzenia, jej troski i nadzieje, rozmowa jej serca z Bogiem, przyrodą i ludźmi. Stąd ta woń i urok, stąd to sympatyczne ciepło, jakie wieje na twarz czytelnika z tych drobnych, polnych kwiatuszków poetycznych. [...] Pochwały oddawane wtedy autorce nie zawróciły jej głowy, nie porwały z cichego ustronia poetycznych zadumań na zakurzony gościniec literackich, rzemieślniczych robótek, jak tyle innych kobiet, które z rękami zaczernionymi atramentem, z oczami szukającymi z umęczeniem natchnień po suficie pokoju zmuszają się do pisania z zapoznaniem rodzinnych obowiązków, świętszych i pewniejszych niż owa sława, za którą gonią, a która rzadko komu wkłada swoje laurowe wieńce. ${ }^{41}$

Jaką więc poetki miały szansę na rozwój, skoro krytyka w większości zbywała ich próby, a recenzje w większości niczego konkretnego nie wnosiły? Zastępczą funkcję wobec braku krytycznoliterackiego komentarza mogły pełnić potyczki poetyckie, w które czasami wchodziły autorki, na przykład wiersz Ilnickiej (Do dziewczyny z różą, B 1865, nr 5) stał się przedmiotem polemiki ze strony niezidentyfikowanego Z. (Druga miłość, B 1866, nr 22), Ilnicka spierała się z Antonim Edwardem Odyńcem (por. tejże Łza - tegoż Uśmiech, KR 1867, nr 6), a Odyniec (KR 1868, nr 8) z Jaskółką (Zeitheim). Pierwszy głos w wierszu Jaskółka należał do Zeitheim i wprowadzał czytelny wątek autotematyczny:

O! bo jaskółka, to ptasze wieszcze,

Czuje pogodę, burze i deszcze,

I potem śpiewa swoje przeczucia,

Za uśmiech, albo za łzę współczucia,

O! wy zwycięskie powietrzne gońce,

Uczcie ją orły! Jak patrzeć w słońce

Sokoły, uczcie ją swego lotu,

Wprost w niebo, mimo błyskawic, grzmotu! ${ }^{42}$

Na te słowa odpowiadał Odyniec (Do Jaskółki), pobłażliwie traktując twórcze aspiracje kobiety i zachwalając skromny obszar aktywności przeznaczanej poetce:

$$
\begin{aligned}
& \text { Na co tobie, Jaskółeczko, } \\
& \text { Orłów lot wysoki, } \\
& \text { Gdy się zwijasz ponad rzeczką, } \\
& \text { Lub śmigasz w obłoki; } \\
& \text { Gdy szybujesz, wzdłuż czy wokół, } \\
& \text { W powietrza przezroczu; }
\end{aligned}
$$

41 „Kalina” 1867, nr 24, s. 7-8. Chodzi o Poezje Krakowianki (Kraków 1842) oraz Nowe poezje Anny L. Krakowianki (Kraków 1846).

42 Jaskółka [J. Zeitheim], Jaskółka, „Kronika Rodzinna” 1868, nr 8, s. 113. 


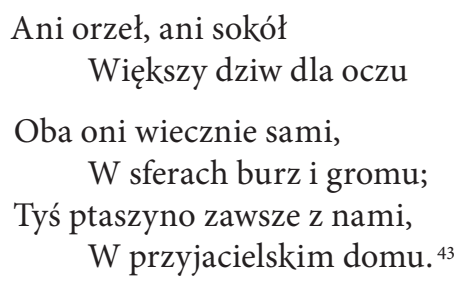

Zapewne zgodzilibyśmy się z nim bez większych oporów, bowiem zdolności Jaskółki nie były najwyższych lotów, gdyby tylko poziom artystyczny riposty Odyńca istotnie uzasadniał takie jednoznaczne werdykty.

\section{ROZDROŻA LIRYKI KOBIECEJ}

Wydaje się, że w pewnym momencie poetki - zwłaszcza te bardziej świadome procesu twórczego - stanęły na rozdrożu, którego istnienie dostrzegano także w badaniach nad angielską liryką kobiecą XIX wieku ${ }^{44}$. Powszechna w epoce pochwała uczuciowości kobiecej zaowocowała u mniej zdolnych a ambitnych autorek setkami podobnych wierszy pisanych z pozycji „ofiary”, której przychodzi „pisać i płakać” ${ }^{5}$. Realizowanie ekspresywno-konfesyjnego modelu poezji w pewnej chwili zaczęło wspierać niepożądany obraz kobiecości, w którym na plan pierwszy wysuwały się atrybuty uznane za nie-męskie, a więc tym samym wykluczające je $\mathrm{z}$ oficjalnego świata literackiego. Chcąc uciec przed taką perspektywą, wpadały w inną pułapkę odbierającą im niezawisłą podmiotowość: albo przejmowały epigońską poetykę męskiej konfrontacji ze światem, albo - paradoksalnie - dochodziły do silnie zniewalającej je konwencji elegijno-melancholijnej. Zniewalającej dodatkowo dlatego, że jej utrwalaniu sprzyjały w Polsce okoliczności społeczno-historyczne. W opinii publicznej lat 1865-1870 efekty tych zmagań musiały en bloc sprawiać wrażenie anachroniczne i potęgować przekonanie, że kobietom brak prawdziwej twórczej energii. Również krytyka nie była gotowa, by szukać nowych idei między wersami, rozszyfrowywać dyskretne ślady emancypowania się poetek, doceniać inność kobiecych emanacji. Wydaje się, że poza nielicznymi przypadkami, patrzono na rzesze piszących kobiet z ogromnym dystansem, w którym założenie niedoskonałości - często nieświadome - przeważało nad uważną lekturą. Trudno się temu dziwić, bo niemało było w tych poetyckich próbach grafomaństwa. Z pewnego czaso-

A.E. Odyniec, Do Jaskótki, „Kronika Rodzinna” 1868, nr 8, s. 113. and Genre, 1830-1900, eds. I. Armstrong, V. Blain, London 1999, s. 390. 
wego oddalenia możemy jednak uznać, że chyba porównywalnie z równie bujną i dyletancką wytwórczością poetów. I że wiele z nich mimo wszystko próbowało szukać nowych środków ekspresji, pozwalających zachować ważne w ich pojęciu doświadczenie emocjonalnego odbioru rzeczywistości, a zarazem uwalniających ich dykcję poetycką od prostej impresyjności na rzecz bardziej metaforycznego czy symbolicznego sposobu wyrażania. Gdy odrzucimy pokusę porównań z kanonem literackim i uwzględnimy status bycia „obok” ówczesnych literatek, mogą wyłonić się interesujące ścieżki dla szukania związków tej liryki zarówno z kobiecą poezją pozytywizmu, jak i modernizmu ${ }^{46}$. W perspektywie rozwoju literatury poetki tego okresu poniosły porażkę, ale mają swoje zasługi - ich zaprezentowaniu służył również obecny przegląd - dla tradycji kobiecego pisania.

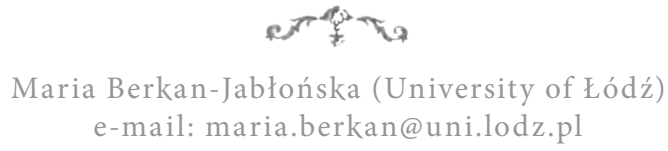

Women's Poetry in Polish Women's and Family Magazines OF $1865-1870$

\section{A B S T R A C T}

The paper presents selected tendencies in Polish women's poetry of 1865-1870 which was a period of a breakthrough between Romanticism and Positivism. The analysis is based on the poems published in several family and female magazines, such as "Opiekun Domowy", "Kółko Domowe", "Kronika Rodzinna", "Tygodnik Mód", "Kalina" and "Bluszcz". Both continuations and epigonic forms in relation to the previous period of literature are discussed, as well as forerunners of new literary phenomena which deserve the special attention of the 19th century researchers. A few suggestions have been made for considering new possible ways of reading seemingly obvious and traditional female poems. The author of the paper also draws attention to the absence of reliable literary criticism which could have a constructive influence on the quality of female poetry and its resulting consequences.

\section{KEYWORDS}

emancipation in literature, poetry of the 19th century, Polish women's poetry, woman author, 19th century women's press

46 Por. m.in.: I. Armstrong, V. Blain, Preface, w: Women'Poetry..., dz. cyt., s. VIII-IX. 